体育学研究, $38: 425-435,1994$.

\title{
少年期におけるサッカーゲームの証知に及ぼす年龄及び競技水準の影霎
}

\author{
工 藤 孝 幾1) 深 倉 和 明11
}

\section{The Effect of Ages and Skill Levels on the Recognition of A Soccor Game}

Koki Kudo ${ }^{1}$ and Kazuaki Fukakura ${ }^{1}$

\begin{abstract}
Chase and Simon (1973) reported that a master class chess player's recall performance of the positions of briefly presented chess pieces was better than that of lesser skilled players. The studies in sport situations that adopted the Chase and Simon's paradigm also demonstrated the same results. The purpose of this study was to investigate the effect of ages and skill levels on the recognition of a soccor in later childhood using the modified Chase and Simon's paradigm. Subjects were 524 boys varied both in soccor skill levels (non-player, irregular-, regular- and selected-) and school years (ranged from fifth graders of elementary schools to second-year students of junior high schools). Immediately after the presentation of 10-minute videotaped soccor game, their recognition accuracy of the game relevant memories and peripheral memories were tested. As has been found for adult subjects, higher skill level players were superior in the performance of relevant memories to lower skill level players and nonplayers. On the other hand, the interaction between skill levels and school years was statistically significant in the peripheral memories. As school years increased, the performance of the highest skill level players significantly declined, whereas no significant change was found in the performance of the lower skill level players and of nonplayers. These results were discussed in terms of the development of encoding strategy for the information from the display. It was inferred that the highest skill level players encoded game information more elaborately than players of other skill level in an early developmental stage.
\end{abstract}

Key words : Recognition of Soccor Game, Age, Skill Level, Selective Attention

(Japan J. Phys. Educ., 38 : 425-435, March, 1994.)

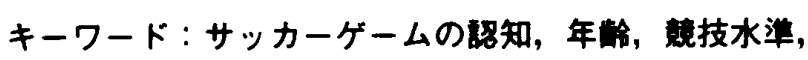
買択的注意

スポーツにおける優秀な競技者が，どのような 側面で優れているのかは，スポーツ科学における 主要な関心事の一つである。とくにボールゲーム を中心としたオープンスキルでは, 状況の認知一 判断の情報処理プロセスが, 優れたプレーを支え
る重要な要因となっているところから，感覚, 知覚, 予測, 反応時間などについて多くの心理 学的研究が行われてきた。 それらについては, Starkes and Deakin ${ }^{22)}$ や Garland and Barry ${ }^{12)}$ が 優れた概括を行っている. Starkes and Deakinは, 競技者の能力を情報処理機構におけるハードウェ アーとソフトウェアーにたとえ，奥行き知覚や各 種の視力，あるいは反応時間などのハードウェ
1) 福島大学教育学部

干960-12 福島市松川町浅川字直道 2 番地
1. The Faculty of Education Fukushima University 2. Matukawa. machi, ' kushimashi. Fukushima (960-12) 
アーの側面が競技レベルを決定する主要な要因で はなく、ゲーム場面からの情報をいかに処理する かというソフトウェアーに相当する要因の方が大 きな役割を果たしていると述べており，Garland and Barry もほほ同様の結論に達している.

このようなゲーム場面からの情報の処理の仕方 に関しては、これまでにいくつかの方法によって 分析が試みられてきた。その代表的なものとして は, 注視点を記録する方法 ${ }^{2.5 .14 .15 .17 .19 .20) や, ~}$ 場面からの情報を部分的に遮断することによっ てパフォーマンスへの影響を比較する部分遮断 法 $^{1-3.13 .23)}$ などがある。ところが, 同じ問題はこ れらの研究にやや先んじて, 認知心理学の領域に おいても検討されている。 それはエキスパートの 知識構造に関する研究である。

Chase and Simon ${ }^{7)}$ は,レベルの異なるチェス プレーヤーに，チェスボードのコマの配列を 5 秒 間観察させ，それらの位置を再生させたところ， 観察したボードが実際のゲームの場面である場 合，マスタークラスの人はAクラスの人より，ま たAクラスの人は初心者よりも再生が正確である が、コマがランダムに並べられたときには，この ような競技レベルによる差は見られないことを報 告している．実際のゲーム場面では競技レベルに よる差がみられ，ランタムに並べられた場合に差 がみられなくなるのは，その差が上級者の記憶容 量の大きさによるものではなく，いかに場面を構 造的に捉えることができるかという点での差であ ることを意味している，つまり，コマの位置を一 つ一つ覚えるのではなく，局面を一つのまとまり （チャンク）として捉え，場面を構造化して見る ことによって情報を効率的に処理しているのであ る. Chiesi et al. ${ }^{9)}$ は, 野球に関する知識を多く持っ ている人の方が，少ない人よりも野球のゲームに 関する文章の内容をよく把握していることを明ら かにしているが，これは過去の経験を通じて獾得 した領域固有の知識の豊富さが，場面を構造化し て見るという能力の決定因子であることを示して いる.

競技レベルとゲーム場面の認知の正確性に関す

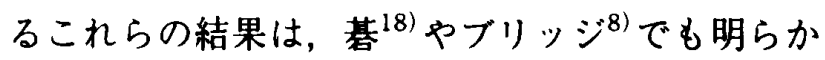

かにされているが, 同じことはボールゲームの競 技者にも当てはまると考えられる。むしろボール ゲームの場合は，常に変化する場面の中で，瞬時 に適切な行動をらなければならないので，場面を 構造的に見ることによる効率的情報処理は，競技 者に要求される重要な資質の一つであるとさえい える. Allard et al. ${ }^{4)}$ は,このような観点から， Chase and Simonの実験パラダイムをバスケット ボールに適用した実験を行っている．彼らは，大 学生女子バスケットボール競技者と一般の女子大 学生を対象に，バスケットボールのゲーム場面を 写したスライドに関する再生の正確性を調べた。

スライドの半分は，一方のチームが攻慗途中の場 面で，構造が比較的明確なものであり，あとの半 分はターンオーバーやリバウンドで敵味方入り乱 れた構造化されていないものであった４４秒間の スライド提示の後, 被験者にプレーヤーの位置を 再生させたところ, 構造化された場面では両群間 に差が見られたのに，構造化されていない方では 差が見られなかったと報告している. Starkes ${ }^{21)}$ は，女子フィールドホッケー選手においても同 様の結果を示している。また Bourgeaud and Abernethy ${ }^{6)}$ は，スライドの代わりに 2 秒から 5 秒の長さに編集したバレーボールのVTR を観察 させることによって，動的な場面に関してもほほ 同様の結果が得られることを報告している.

以上に示した研究では，いずれもゲームの中の 部分的な局面を観察し，その都度再生を求めると いう手法を用いている。しかし，もしゲームを意 味のある構造として認知しているのであれば，観 察したゲーム場面の内容はもっと長期にわたって 保持されているはずである. Allard et al. ${ }^{4)}$ は, 前述した実験に続き，実験に用いた一連のスライ ドを被験者が記憶しているかを調べたところ，構 造化されているスライドに関しては，競技者の方 がよく記憶しているということを報告している. 彼らはこの結果に対し，競技者は構造化されたス ライドの情報をより深いレベルで処理しているか らであると解釈している。

この点に関して工藤と深倉 ${ }^{16)}$ は，スライドや 数秒の VTRによる断片的な場面提示ではなく， 
実際のサッカーのゲームを収録した10分間の VTR を一気に観察させ，その内容に関する記憶 をテストするという方法によって分析を行った。 そのときの記憶テストには，ゲームの流れに直接 関連する項目と,ゲームには関連しない周辺の出 来事に関する項目とが含まれていた，関連記憶で は競技レベルによる差が見られるのに対して，周 辺記憶では差が見られないであろうと予想され た. その結果, 周辺記憶において予想と一部矛盾 する結果が見られたものの, 関連記憶に関しては ほほ予想通りの結果が得られた。つまり, 大学生 を対象とした奉験では，全国レベルのサッカー部 員, 地区レベルの大学サッカー部員, 一般学生の 順で記憶得点が優れており，また小・中学生を対 象とした実験でも，競技者と一般の間に差が見ら れた．ただし，競技者内の競技レベルによる有意 な差は見られなかった。

ゲーム場面の認知に関するこれらの研究は, 工 藤と深倉の研究例を除けば他はすべて成人を対象 にしたものである。しかし,, ボールゲームの場 面に対する構造的な見方がいつ頃から発達するの か，また競技レベルと発達との間にどのような交 互作用が見られるのかという問題は，理論的にも 実際的な意味においてもきわめて興味深い問題で ある. 残念ながら工藤と深倉の研究では, サンプ ル数が少なく，この問題に対する情報が十分に得 られているとはいい難い。そこで本研究では，サ ンプル数を増やすことにより, 小学 5 年から中学 2 年までの 4 年間で, 競技レベルの異なる子供が, ゲーム場面の認知においてどのような発達様相を 示すのかを再度明らかにすることを目的とした。
方

法

\section{1. 被唋者}

小学 5 年から中学 2 年までの男子生徒を対象と した. 具体的には, 福島県内の小学校と中学校そ れぞれ 4 校のサッカー部員と, 学校の授業以外, サッカーの訓練を特別受けたことのない一般生 徒, 及び「トレセン」のメンバーである。「トレ セン」とは，県内を大きく 5 地区に分け，それぞ れの地区のサッカー部員の中から選抜された優秀 な選手を対象に、週に 1 回的 2 時間開設されるト レーニングセンターの略称である。 今回対象とし たのはそのうちの 4 地区の「トレセン」のメンバー である. 小学校, 中学校のそれぞれ 4 校は, 今回 対象とした四つの「トレセン」の地区内から，そ れぞれの地区において平均的な競技レベルにあ ク,また週 $4 \cdot 5$ 日, 平均 2 時間程度の練習を行っ ているクラブという基準で, 各地区 1 校ずつ選ば れたものである。一般生徒は，これらの八つの学 校の生徒の中から, 先に述べたような基準で無作 為に選んだ。

「トレセン」のメンバーは, 地区のトレセン担 当者が競技レベルの高い選手を各地区のサッカー 部員の中から選抜したものである. 従って本研究 では, 彼らを最も競技レベルの高い群として位置 づけ,「選抜群」と命名した。サッカー部員は更に， クラブ内でレギュラー選手であるか補欠選手であ るかによって、「正選手群」と「補欠群」とに分 けた。この他に，先に述べた一般生徒を「一般群」 とし，あわせて四つの群を構成した．各学年にお けるそれぞれの競技レベルの被験者の人数を表 1 に示した。

衰 1 本研究の被験者の内訳（単位は人数）

\begin{tabular}{|c|c|c|c|c|c|}
\hline 競技レベル & 小学 5 年 & 小学 6 年 & 中学 1 年 & 中学 2 年 & 合 \\
\hline 一般群 & 41 & 37 & 25 & 42 & 145 \\
\hline 補 欠 群 & 23 & 20 & 34 & 21 & 98 \\
\hline 正選手群 & 29 & 39 & 23 & 32 & 123 \\
\hline 選抜群 & 25 & 57 & 39 & 37 & 158 \\
\hline 合 計 & 118 & 153 & 121 & 132 & 524 \\
\hline
\end{tabular}




\section{2. 鱾愔課原}

本研究で用いたサッカーゲームの記憶課題は， 1974年ワールドカップの旧西ドイッとオランダの 決勝戦の $16 \mathrm{~mm}$ フィルム（日本サッカー協会製 作，ワールドサッカー名勝負シリーズ, No.20) から，前半試合開始後10分間をVTRに収録した ものである。この試合を採用したのは，比較的古
いフィルムであり，被験者の子供たちにとっては 初めて見るゲームの場面であると予想されたこ と，短い時間の中に印象に残ると思われる出来事 が多く含まれていたことなどによる．それらの出 来事のうち,例えば「キックオフから最初のファー ルまでのボールの動き」や「そのファールが起き たときの人のいた場所」などのように，ゲームに
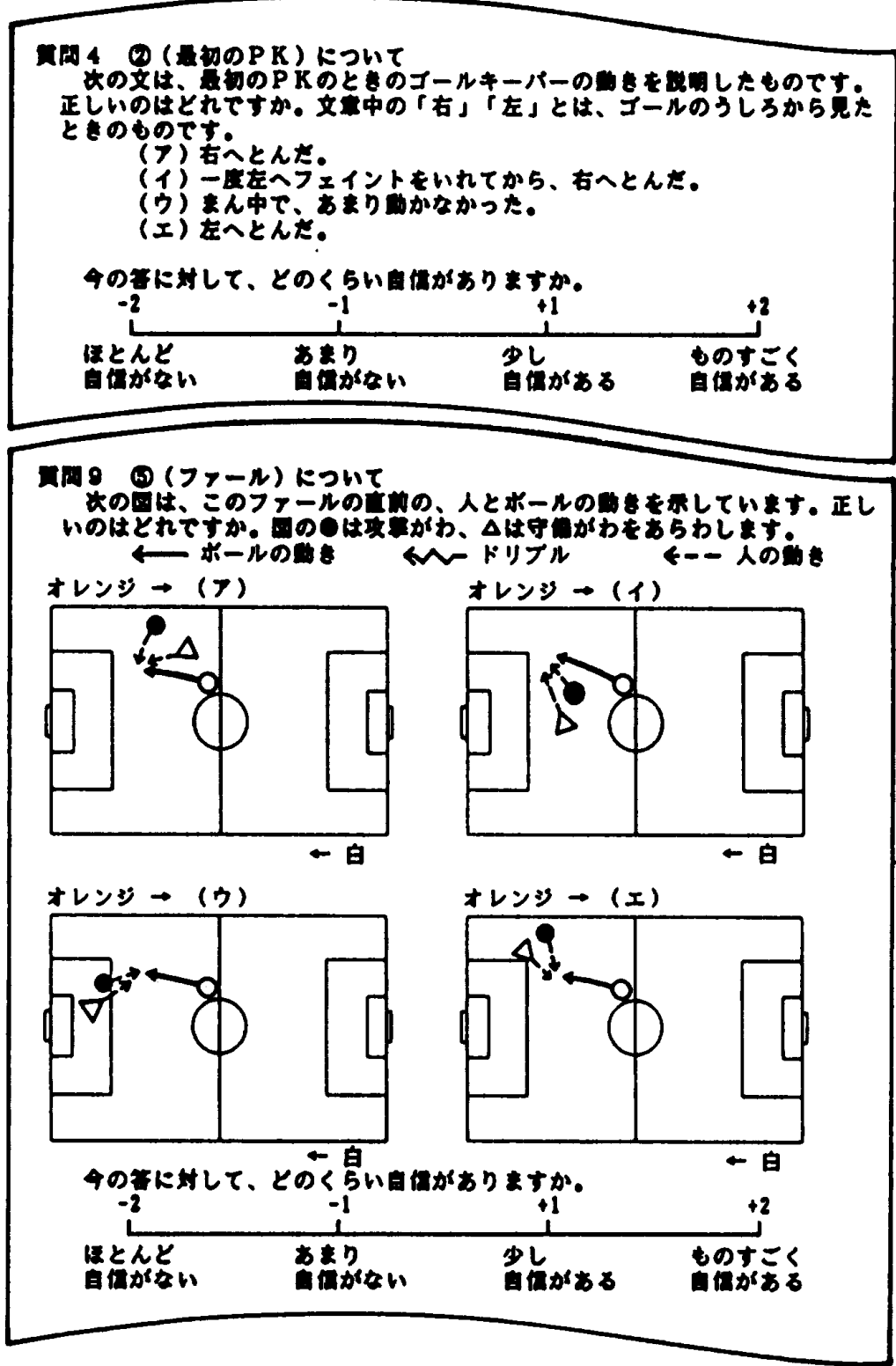

図1選択肢が文章の場合と闵の場合の問題例. 質問番号の直 後の○で用んだ番号は，手挂かり用の略図に示されてい る出来事発生順序の番号である. 質問 9 の選択肢の中の 「オレンジ」白」とは，チームのユニフォームの色を 表している. 
直接関連する14項目の内容（関連記憶）と,「キー パーのユニフォームの色」や「ゴールラインの後 ろ側にカメラマンがいたか」など, サッカーの試 合とは直接関連しない 8 項目の内容（周辺記憶） についての記憶の正確性を調べた。

記憶テストは，四つの選択肢の中から正しいも のを一つ選ぶ再認法によって行った。選択肢は， 簡単に文章表現できる場合は文章で示したが, 複 雑な場面については，ボールと人の针きを表す図 によって示した，再生法の可能性についても検討 したが，動的な動きを再生させる場合，言葉や描 画によらざるを得ず，その場合は被験者の表現能 力の個人差が問題となる．また，表現能力の個人 差ができるだけ関与しないようにすると，設問内 容が著しく制限されてしまう。このような理由で 本研究では再認法を採用したが, 再認法の欠点を できるだけ補う目的で，関連項目については，回 答直後にその回答に対してどの程度自信があるか を 4 段階で評定するよう求めた。こうすることに より，たとえ同じ正答でも，その記憶がどの程度 鮮明であったかもわかるようにした，図 1 は，選 択肢が図の場合と文章の場合の問題をそれぞれ 1 問ずつ例示したものである。

\section{3. 手綍を}

各学校にあるモニターテレビの大きさに応じ て，VTRを見るのに無理のない範囲で複数の被 験者に対して同時に実験を行った，実験に先立っ て被験者には，VTR 終了直後に，その内容につ いていくつかの質問をすることを予告した，10分 間のVTR を観察した後に, 記憶の検査用の小冊 子を配布した。このとき，各設問に使われた出来 事を特定するために，それらの出来事の内容と発 生場所, 及び発生順序を示す番号の晴いてある サッカーグランドの略図もあわせて配布した．記 入上の注意を与えた後, 各自のペースで答えさせ た.

\section{4. 依存变数}

正答を 1 点, 誤答を 0 点として関連記憶項目, 周辺記憶項目ごとに合計点を求め，それぞれを関
連記憶得点, 周辺記憶得点とした。関連記憶の満 点は14点, 周辺記憶の満点は 8 点である. 自信得 点は，0点(ほとんど自信がない)から 3 点（ものす ごく自信がある) までの簀囲で点数化し，正答の 場合の合計点を求めて正答数で割ることにより, 平均自信得点を算出した。

\section{結果と考察}

表 2 に，各依存変数における学年と競技レベル ごとの平均と標準偏差を示した，図 2 は関連記憶 得点について, 各競技レベル群の発達に伴う変化 を示したものである. 分散分析の結果，いずれの 要因の主効果も有意であった（学年要因：F= $10.460, \mathrm{df}=3 / 508, \mathrm{p}<.01$; 競技レベル要因： $\mathrm{F}=28.996, \mathrm{df}=3 / 508, \mathrm{p}<.01)$. それぞれの 要因に関して多重比較（Newman-Keuls test）を 行ったところ, 学年要因では, 小学校 5 年と中学 校 1 年及び中学 2 年との間に $1 \%$ レベルで, 小学 校 6 年との間に $5 \%$ レベルで差が見られ，また小 学 6 年と中学 2 年との間にも $5 \%$ レベルで差が見 られた．小学 6 年と中学 1 年，あるいは中学 1 年 と中学 2 年との間に有意差は見られなかったが, 全体的に見れば，今回対象としたこれらの 4 年間 で, 徐々に関連記憶の得点が向上していることが わかった，競技レベル要因では，一般群と補欠群 間，正選手群と選抜群間では $5 \%$ 多べ，それ以 外では $1 \%$ レ゙ルで, 全ての群間に有意な差が見 られた。

図 3 は平均自信得点の各競技レベル群の発達に 伴う変化を示したものである．分散分析の結果, 競技レベル要因の主効果のみが有意であった（F $=28.325, \mathrm{df}=3 / 508, \mathrm{p}<.01)$. 多重比較をし たところ，一般群と他の全ての競技レベル群との 間に1\%レベルで差が見られ，また補欠群と正選 手群及び選抜群との間にも5\%レベルで差が見ら れた。

発達あるいは競技レベルの向上に伴い，関連記 憶得点, 平均自信得点のいずれにおいても增加が 見られるだろうと予想したが，以上のように，競 技レベル要因に関しては予想通りの結果が得られ た。平均自信得点における正選手群と選抜群間の 
変 2 各依存変数における学年，及び競技レベルごとの平均（M）と標準偏差（SD）

\begin{tabular}{|c|c|c|c|c|c|c|c|c|c|c|}
\hline \multirow{2}{*}{\multicolumn{2}{|c|}{$\frac{\text { 変 数 }}{\text { 関連記憶得点 }}$}} & \multirow[t]{2}{*}{ 競技レベル } & \multicolumn{2}{|c|}{ 小学 5 年 } & \multicolumn{2}{|c|}{ 小学 6 年 } & \multicolumn{2}{|c|}{ 中学 1 年 } & \multicolumn{2}{|c|}{ 中学 2 年 } \\
\hline & & & $M$ & SD & $\mathbf{M}$ & SD & M & SD & $M$ & SD \\
\hline & & 一般 群 & 4.78 & (1.94) & 4.56 & $(2.28)$ & 5.56 & $(2.08)$ & 5.91 & $(2.10)$ \\
\hline & & 補 久群 & 5.18 & $(2.20)$ & 5.25 & (2.24) & 6.41 & $(2.14)$ & 6.21 & (2.16) \\
\hline & & 正選手群 & 6.23 & $(2.04)$ & 6.75 & (2.18) & 7.13 & $(2.35)$ & 7.62 & (1.79) \\
\hline & & 選 抜 群 & 6.61 & $(2.20)$ & 7.24 & (2.05) & 7.40 & $(1.93)$ & 8.42 & $(1.31)$ \\
\hline \multirow{5}{*}{\multicolumn{2}{|c|}{ 平均自信得点 }} & & M & SD & $\mathbf{M}$ & SD & M & SD & M & SD \\
\hline & & 一 般 群 & 1.20 & $(0.69)$ & 1.04 & $(0.69)$ & 1.26 & $(0.55)$ & 1.45 & $(0.58)$ \\
\hline & & 補 欠群 & 1.82 & $(0.70)$ & 1.47 & $(0.67)$ & 1.66 & $(0.44)$ & 1.76 & $(0.67)$ \\
\hline & & 正選手群 & 1.99 & $(0.51)$ & 1.81 & $(0.49)$ & 1.68 & $(0.61)$ & 1.88 & $(0.63)$ \\
\hline & & 選抜群 & 1.88 & $(0.43)$ & 1.90 & $(0.47)$ & 1.84 & $(0.59)$ & 1.74 & $(0.55)$ \\
\hline \multirow{5}{*}{\multicolumn{2}{|c|}{ 周辺記境得点 }} & & M & SD & M & SD & M & SD & M & SD \\
\hline & & 一 般 群 & 3.53 & $(1.19)$ & 3.35 & (1.49) & 3.06 & $(1.35)$ & 3.57 & (1.37) \\
\hline & & 補 欠 群 & 4.09 & $(1.33)$ & 3.58 & (1.44) & 3.61 & $(1.45)$ & 4.29 & $(1.40)$ \\
\hline & & 正選手群 & 4.20 & $(1.34)$ & 3.70 & (1.39) & 3.84 & $(1.09)$ & 4.50 & (1.50) \\
\hline & & 選抜群 & 4.23 & $(1.24)$ & 4.62 & $(1.45)$ & 4.07 & $(1.28)$ & 3.61 & $(1.41)$ \\
\hline
\end{tabular}

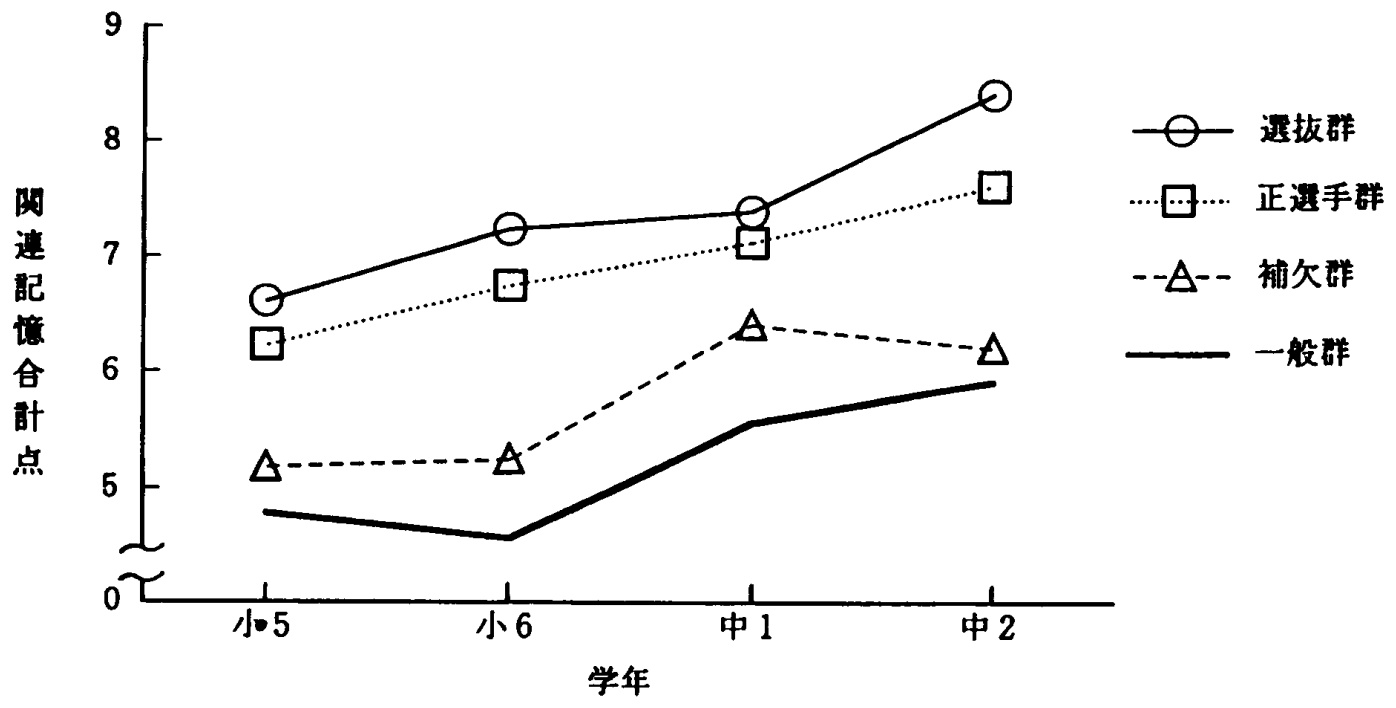

図 2 各親技レベルにおける関連記憶合計点の発達棣相

差は見られなかったものの，全体としては競技レ ベルが上がるほど記憶が多く，しかもより鮮明で あることがわかる。これに対して，発達要因の方 は，関連記憶得点で主効果が有意であったが，予 想とは異なり，平均自信得点では主効果は見られ なかった。たた，自信の程度に変化がなく，記憶 数が増えたということは，発達に伴う記憶数の增 加があいまいなものを多く含んだ見かけの増加で
はなく，同程度の鮮明さを伴った実質的な記憶数 の增大であることを意味している。

さて, 関連記憶においては, 小学 5 年から中学 2 年の 4 年間で, 徐々に得点が上昇しているが, このことは，今回調べた 4 年間においては，ある 時期に急激に認知の仕方が変化するといった郜界 期のようなものは存在しないことを意味してい る。また競技レベルの方では，今回設定した全て 


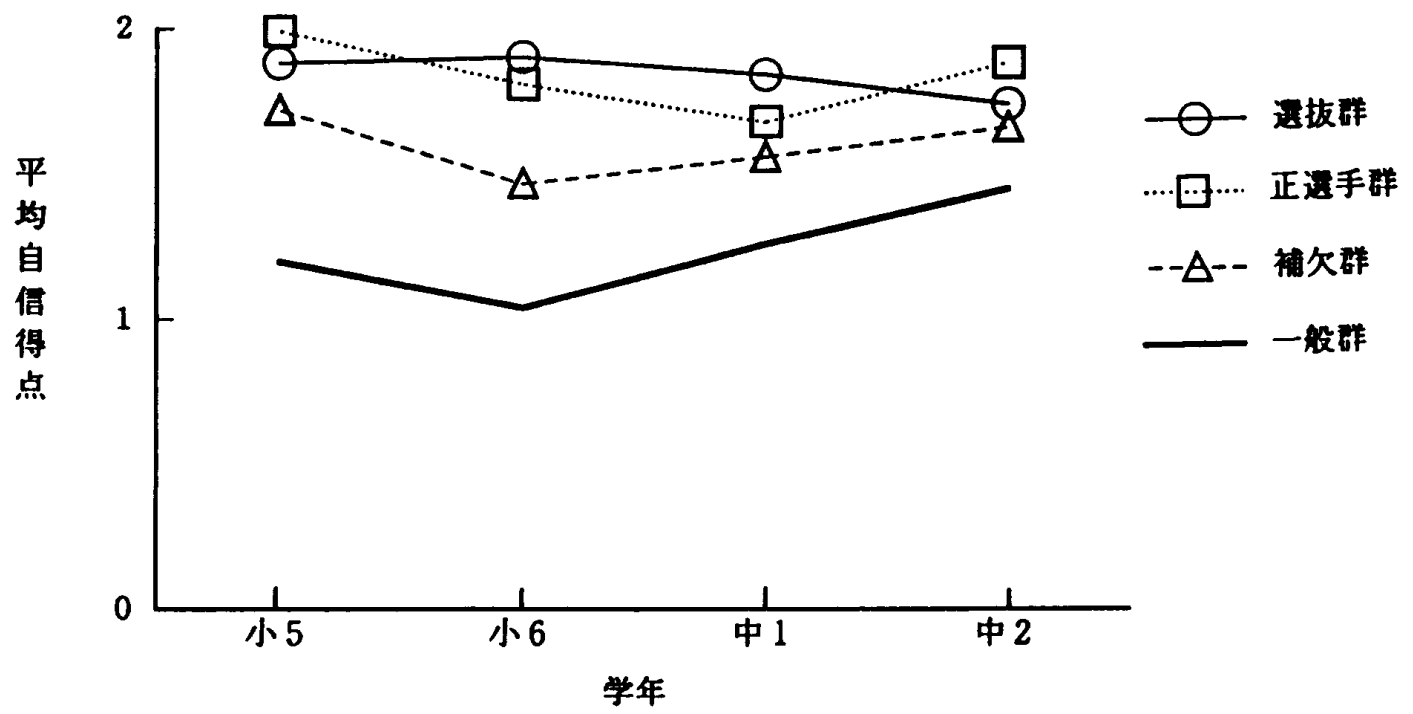

図 3 各競技レベルにおける平均自信得点の発達様相

のレベル間に有意差が見られた。このことは，直 後再生のパラダイムを用いたこれまでの研究と一 致しているが，それらの研究が全て成人を対象に していたことを考えると, 小学校高学年から中学 校までの発達段階でも同様の結果が得られたこ と,しかも一般生徒と経験者の 2 分割だけでなく， 経験者の中を更に 3 ランクに分けた場合でも，全 てのレベル間で有意差が見られたことは非常に興 味深い結果である。つまり，一般群と他の三つの 競技者群との差は, 小学校 5 年の発達段階でも一 定の経験や訓練を積むことによって場面を跷造的
に見るという能力が開発されることを意味してい る。また競技者の 3 群間の差異は，既にこの発達 段階において，場面の構造的な見方が競技レベル と密接に関わっていることを意味している.

図 4 は周辺記憶得点について，各競技レベル群 の発達に伴う変化を示したものである．分散分析 の結果, 学年要因の主効果は見られず, 競技レベ ル要因の主効果, 及び学年要因と競技レベルの要 因の交互作用が有意であった（竸技レベル要因： $\mathrm{F}=7.236, \mathrm{df}=3 / 508, \mathrm{p}<.01$; 交互作用 $: \mathrm{F}$ $=1.897, \mathrm{df}=9 / 508, \mathrm{p}<.05)$. 交互作用が有

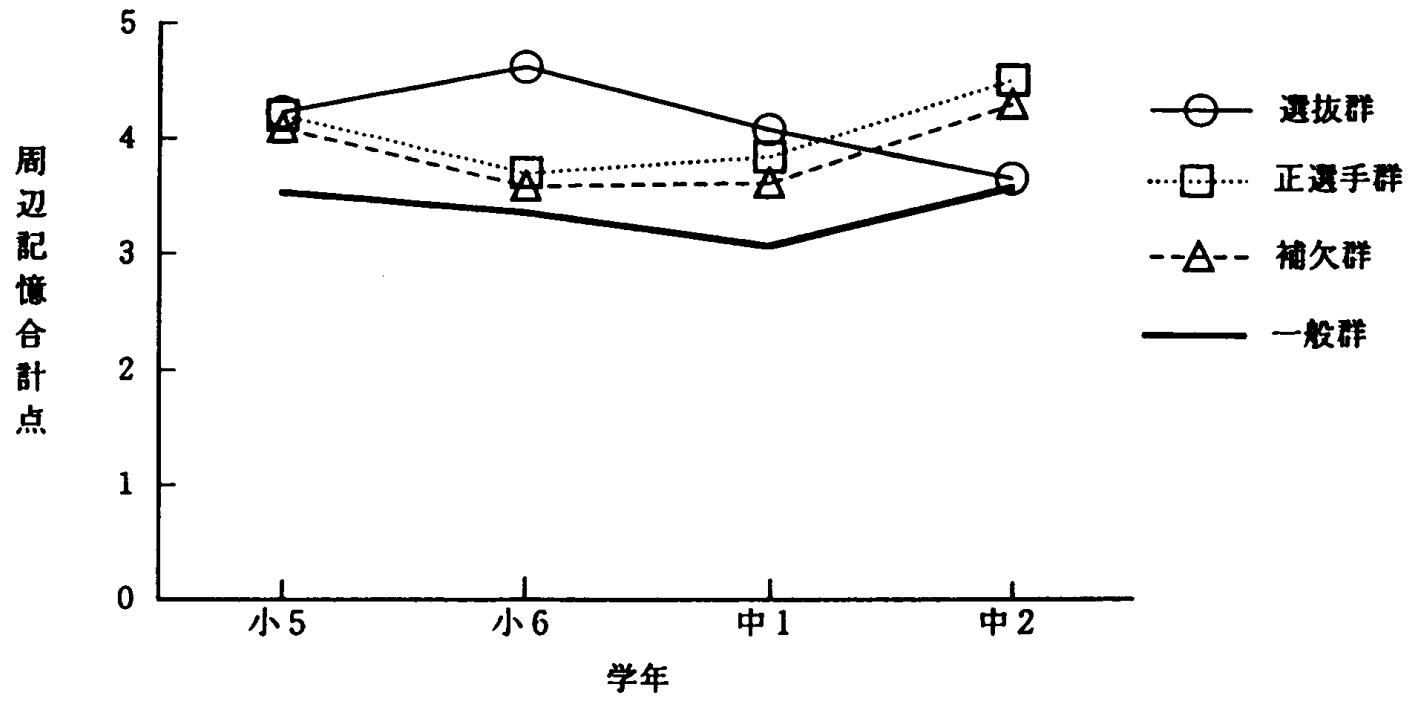

图 4 各競技レベルにおける周辺記境合計点の発達様相 
意であったので，各学年ごとに競技レベル要因の 単純主効果の検定を行ったところ，小学 5 年以外 の三つの学年において有意であった（小学 6 年 : $\mathrm{F}=7.600, \mathrm{df}=3 / 508, \mathrm{p}<0.1$; 中学 1 年 : $\mathrm{F}$ $=2.808, \mathrm{df}=3 / 508, \mathrm{p}<.05 ;$ 中学 2 年 $: F=$ 3.852 , df $=3 / 508, \mathrm{p}<.01)$. それぞれに関し て多重比較を行ったところ, 小学 6 年では選抜群 と他の 3 群との間に $1 \%$ \%ベルで差が見られ，中 学 1 年では選抜群と一般群との間のみに $5 \%$ レベ ルで差が見られ, 中学 2 年では正選手群と一般群 及び選抜群との間に $5 \%$ \%ベルで差が見られた。 また，各競技レベルごとに学年要因の単純主効果 の検定を行ったところ，選抜群のみにおいて有意 であり $(\mathrm{F}=4.067, \mathrm{df}=3 / 508, \mathrm{p}<.01)$, 正 選手群で有意の傾向が見られた（F=2.228, df $=3 / 508, \mathrm{p}<.10)$ ．選抜群に関して多重比較を した結果, 小学 6 年と中学 2 年の間に $5 \%$ レベル で差が見られた。

周辺記憶とは，ゲーム場面を構造的に見ること とは直接関係しないものであり，発達や竸技レベ ルによる直接的な影䇾は見られないだろうと予想 されたが，実際には以上のように，発達要因と競 技レベル要因の交互作用が有意であった.つまり， 選抜群では小学 6 年生において得点がピークに達 し，それ以降低下するのに対し，他の 3 群では統 計的には学年による有意な変化が見られなかっ
た。選抜群において， 6 年以降周辺記憶の得点が 低下するのに関連記憶で得点が向上し続けるとい うことは，6年を境としてゲームの流れとは直接 関連しない周辺の出来事に対する注意の分散を抑 えゲームに関連する出来事に注意を集中させる という選択的注意の方略がとられ始めていること を強く示唆している.

そこでこのことを確かめるために，個人ごとに 関連記憶正答数に対する周辺記憶正答数の割合を 求め，それを「選択的注意指数」として分析を行っ た。この指数が小さいほどゲームに関連する側面 により選択的に注目していたことを意味する。た だそれぞれの問題数も異なり，また難易度の統一 を図っているわけでもないので，この指数の値そ のものがなんらかの絶対的意味を持っているわけ ではない.

図 5 は選択的注意指数について，各競技レベル 群の発達に伴う変化を示したものである，分散分 析を行ったところ，二つの要因の主効果及び交互 作用の全てが有意であった（学年要因： $F=$ $7.350, \mathrm{df}=3 / 508, \mathrm{p}<.01$; 競技レベル要因 : F $=5.127, \mathrm{df}=3 / 508, \mathrm{p}<.01$; 交互作用 : F $=$ $2.297, \mathrm{df}=9 / 508, \mathrm{p}<.05)$ ，そこで, 各学年 ごとに競技レベルの単純主効果の検定を行ったと ころ, 小学 6 年と中学 2 年において有意であった (小学 6 年 $: F=2.840, \mathrm{df}=3 / 508, \mathrm{p}<.05$;

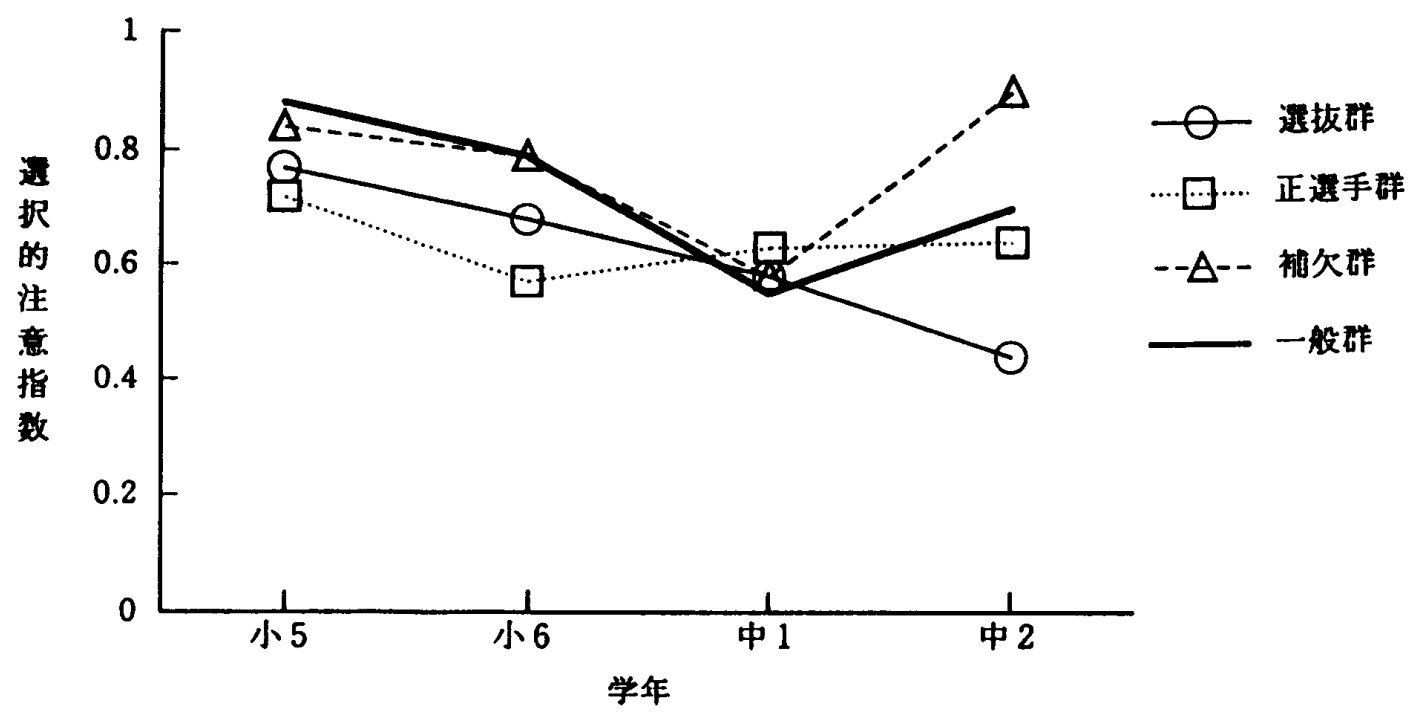

图 5 各䗷技レベルにおける選択的注意指数の発達様相 
中学 2 年: $F=7.621, \mathrm{df}=3 / 508, \mathrm{p}<.01)$. 多重比較を行ったところ, 小学 6 年では正選手群 と一般群及び補欠群との間に5\%レベルで有意差 が見られ，中学 2 年では，一般群と正選手群間以 外の全ての群間に有意差が見られた（補欠群と選 抜群の間だけ $1 \%$ レベル，それ以外は全て $5 \%$ レ ベルの有意差)。また，各競技レベルごとに学年 要因の単純主効果の検定を行ったところ，正選手 群を除く他の 3 群において有意であった（一般群 $: F=4.708, \mathrm{df}=3 / 508, \mathrm{p}<.01 ;$ 補欠群 $: \mathrm{F}$ $=4.182, \mathrm{df}=3 / 508, \mathrm{p}<.01$; 選抜群 $: \mathrm{F}=$ $5.055, \mathrm{df}=3 / 508, \mathrm{p}<.01)$. 多重比較を行っ たところ，一般群では中学 1 年が小学 5 年と $1 \%$ レベルで, 小学 6 年と $5 \%$ \%ベルで差が見られた. 補欠群では中学 2 年が他の全ての学年と $5 \%$ レ゙ ルで異なっていた，選抜群では, 中学 2 年が小学 5 年と $1 \%$ レベルで, 小学 6 年と $5 \%$ レベルで差 が見られた。

このように，選択的注意指数においては，競技 レベルによってそれぞれ異なる発達的な変化のパ ターンが見られた。つまり，一般群と補欠群はと もに中学 1 年まで指数が低下し，中学 2 年でまた 上昇に転じるのに対し，正選手群では学年に伴う 変化が見られず，また 4 群の中で最も競技レベル の高い選抜群では, 小学 5 年以降一貫して指数が 低下し続けるということである。

このうち, 正選手群では学年による選択的注意 の仕方に変化が見られず，選抜群で徐々に選択的 に注意する傾向が強まるという結果は, 発達と共 に選択的注意というものが，優れたプレーヤーの 特徽的な認知の仕方となっていくことを示してい る.また, 補欠群の選択的注意指数が中学 1 年か ら 2 年にかけて高くなっているのは, 中学 1 年に おいては競技レベルに関わらずほとんどが補欠で あるのに対し, 中学 2 年では技能の程度による選 別がなされているという事情が反映したものと考 えられる.従って，補欠群における以上の結果も， 選択的注意と竸技レベルとが密接に関わっている ことを示す一つの証拠となっていると考えられ る.

さて，今回得られた結果全体からいえることは，
ゲーム場面を構造的に見るという認知の仕方が, 既に小学校高学年の段階で競技レベルと深く関 わっているということである。ただ，そのような 認知の仕方が競技レベル差をもたらしたのか，あ るいは競技レベルの相違に伴う経験の差が認知の 仕方の差の原因となったのかなどについては，残 念ながら今回の結果からはわからない。これらの 点は，今後実験的な研究によって明かにされなけ ればならないだろう。

本研究では，ゲーム場面の構造的な見方の発達 を、観察したゲームに関する記憶の正確性という 観点から分析した．ところで,このような経験に 伴う記憶についてコーエン ${ }^{10)}$ は，個人的に経験 したことを記憶していることは，その時点で抱え ている問題に対処するための解決策を蓄えること でもあると述べているが, サッカーゲームの経験 を通じて得られた記憶には，このような実際的な 意味も含まれている。つまり，経験に関する記憶 とはその領域に固有の知識であるともいえる。 従って, 早期に楎造的な見方が可能になることは， それだけ領域固有の知識を蓄積することができる ということであり，このことが競技レベルの差の 一つの原因となっているとも考えられる.

\section{ま と め}

本研究では，ゲーム場面の構造的な見方がどの ように発達するのかを，観察したゲームの内容に 関する記憶を分析することによって明らかにしよ うとした.小学 5 年生から中学 2 年生までの, サッ カ一の競技水準において異なる四つの群に対し， 10分間のサッカーのゲームの VTR を観察させ, その内容に関する記憶テストを行った。その結果, ゲームに直接関連する記憶においては，学年が進 むにつれて記憶得点が向上すること，また，全て の学年を通じクラブ経験の有無や競技レベルの相 違によって記憶得点に差が見られることが明らか となった。

周辺記憶においては，発達や竸技レベルにとも なう差は見られないだろうと予想されたが，実際 にはこれらこつの要因間に交互作用が見られた。 つまり, 選抜群では小学 6 年生において得点がピ 
一クに達し，それ以降低下するのに対し，他の 3 群では統計的には学年による有意な変化が見られ なかった。

\section{また，関連記憶数と周辺記憶数の割合から選択} 的注意指数を算出して分析した結果，競技レベル によって異なる発達的な変化が見られた。つまり， 最も競技レベルの高い選抜群のみが小学 5 年以降 一貫して指数が低下し続けるのに対し，他の 3 群 では指数の低下は見られなかった。

これらの結果は, 小学校高学年という発達段階 においても，特別の経験や訓練によってゲーム場 面を粠造的に捉える能力が開発されるものである こと，またこの時期において既にそのような認 知の仕方が競技レベルと密接に関わっていること を示している。

（的辞：本研究を実施するにあたり，多大なご協力と ご理解を賜りました協力校の先生，クラブ及びトレセ ンの指導者の方，そして実験を手伝ってくれた研究室 の学生の皆さんに, 深く感樈いたします.)

\section{文神 (References)}

1) Abernethy, B. (1990) Anticipation in squash : differences in advance cue utilization between expert and novice. Journal of Sport Sciences $8: 17-34$.

2) Abernethy, B. and Russell, D. G. (1987) Expertnovice differences in an applied selective attention task. Journal of Sport Psychology $9: 326-345$.

3) Abernethy, B. and Russell, D. G. (1987) The relationship between expertise and visual search strategy in a racquet sport. Human Movement Science,6 : 283-319.

4) Allard, F., Graham, S. and Paarsalu, M. E. (1980) Perception in sport: basketball. Journal of Sport Psychology $2: 14-21$.

5) Bard, C. and Fleury, M. (1976) Analysis of visual search activity during sport problem situations. Journal of Human Movement Studies $3: 214-222$.

6) Borgeaud, P. and Abernetht, B. (1987) Skilled perception in volleyball defense. Journal of Sport Psychology $9:$ 400-406.

7) Chase, W. G. and Simon, H. A. (1973) Perception in chess. Cognitive Psychology $4: 55-81$.

8) Charness, N. (1979) Components of skill in bridge.
Canadian Journal of Psychology 33, : 1-16.

9) Chiesi, H. L., Spoilich, G. J. and Voss, J. F. (1979) Acquisition of domain-related information in relation to high and low domain knowledge. Journal of Verbal Leaning and Verval Behavior,18:257-273.

10）コーエン：川口他訳 (1991) 日常記境の心理学 サ イエンス社：東京, p. 125 (G. Cohen 1989 Memory in the Real World. Lawrence Erlbaum Associates Ltd.).

11) Craik, F. I: and Lockhart, R. S. (1972) Level of processing : a framework for memory research. Jour. nal of Verbal Learning and Verbal Behavior 11 : 671-684.

12) Garland, D. J. and Barry, J. R. (1990) Sport expertise : the cognitive advantage. Perceptual and Motor Skills $70: 1299-1314$.

13) Goulet, C., Bard, C. and Fleury, M. (1989) Expertise differences in preparing to return a tennis serve: a visual information processing approach. Journal of Sport \& Exercise Psychology $11: 328-398$.

14）出村慎一・石村宇佐一（1984）ボールゲームにおけ る注視点の分析一バスケットボールースポーツ心 理学研究 $11: 36-38$.

15）金本益男・中村誡・破川正教（1979）コールキー パーの注視行動に関する研究 東京都立大学体育学 研究 2-1:29-34.

16）工藤孝阵・樑會和明（1992）ゲームに関する記境と 新技水漸との関係 平成 3 年度日本体育協会スポー ツ医・科学研究報告, No. V, スポーツタレントの 発掘方法に関する研究 第 3 報. 日本体育協会 81 86.

17）中山雅雄 (1987) サッカーのコールキーパーの注視 行功について スポーツ心理学研究 14:147-149.

18) Reitman, J. S. (1976) Skilled perception in Go: deducing memory structures from inter-response times. Cognitive Psychology $8: 336-356$.

19) Ripoll, H. (1989) Uncertainty and visual strtegies in table tennis. Perceptual and Motor Skills $68: 507-$ 512.

20) Shank, M. D. and Haywood, K. M. (1987) Eye movements while viewing a baseball pitch. Perceptual and Motor Skills $64: 1191-1197$.

21) Starkes, J. L (1987) Skill in field hockey : the nature of the cognitive advantage. Journal of Sport Psychology $9: 146-160$.

22) Starkes, J. L. and Deakin, J. (1984) Perception in sport : a cognitive approach to skilled perfomance. In 
W. F. Williams, (Eds.), Cognitive Sport Psychology. Sport Sport Science Associates Lasting. New York. pp. 115-128.

23) Wright, D. L. Pleasants, F. and Gomez-Meza, M. (1990) Use of advanced visual cue sources in volleyball. Journal of Sport \& Exercise Psychology $12: 406-414$.
(平成 5 年 4 月 12 日受付

平成 5 年 9 月 25 日受理 